\title{
Effect of dietary protein levels on the growth of Carnatic carp Barbodes carnaticus (Jerdon, 1849) fingerlings
}

\author{
N. SRIDHAR, B. GANGADHAR, UMALATHA, C. H. RAGHAVENDRA, S. S. GIRI* AND \\ P. JAYASANKAR* \\ Regional Research Centre of ICAR-Central Institute of Freshwater Aquaculture, Hesaraghatta Lake P.O. \\ Bangalore - 560 089, Karnataka, India \\ "ICAR-Central Institute of Freshwater Aquaculture, Kausalyaganga, Bhubaneswar - 751 002, Odisha, India \\ e-mail: sridharcifa@rediffmail.com
}

\begin{abstract}
Fingerlings of Barbodes carnaticus (Jerdon 1849) $(6.40 \pm 0.267 \mathrm{~cm}, 2.46 \pm 0.39 \mathrm{~g})$ were reared in aerated plastic tubs (40 1) with five iso-energetic diets formulated to contain crude protein levels ranging from 25 to $45 \%$ using pure ingredients. Initially, the diet was fed at @ $5 \%$ of the biomass and gradually adjusted based on daily feed consumption. The fish were allowed to feed for $6 \mathrm{~h}$ and thereafter the unconsumed feeds were siphoned out. The following day, faecal matter was collected from each tank by filtering the water with a fine meshed nylon cloth $(15 \mu \mathrm{m})$, dried, pooled and stored for proximate analysis. Water from each tub was replaced with $50 \%$ freshwater every day after faecal matter collection. The feeding trial was conducted for a period of 60 days. Proximate composition of feed and faecal matter was analysed. Acid insoluble ash was used as the reference marker for dry matter, protein and fat digestibility determination. The growth parameters and protein efficiency ratio (PER) were higher $(\mathrm{p}<0.05)$ in fish fed $35 \%$ protein diet compared to other diets. The feed conversion ratio (FCR) was lower ( $<<0.05)$ in 35,40 and $45 \%$ protein diets compared to the lower protein diets. The carcass proximate composition revealed the lowest moisture $(\mathrm{p}<0.05)$ and highest protein $(\mathrm{p}>0.05)$ and fat content $(\mathrm{p}<0.05)$ in fish fed $35 \%$ protein diet compared to other diets. The digestibility of dry matter and nutrients was higher $(\mathrm{p}<0.05)$ with $35 \%$ protein diet. The study revealed crude protein requirement of $35 \%$ by the fingerlings of $B$. carnaticus.
\end{abstract}

Keywords: Barbodes carnaticus, Dietary protein, Fingerlings

Indian major carps contribute the lion's share to freshwater aquaculture production in India, around $80 \%$ by volume. India is regarded as a 'carp country' due to the rich diversity of carps in its freshwater ecosystems. The country is blessed with 15-20 varieties of minor carps that have a huge potential for freshwater aquaculture, yet to be exploited. A need for diversification of farmed fish species has been emphasised (NACA/FAO, 2000). These carp species, some of which belong to the minor carps, can be considered as alternatives to the major carp species for diversification in freshwater aquaculture. Barbodes carnaticus (Jerdon 1849), commonly known as Carnatic carp, is one such species endemic to the Western Ghats of India. The breeding technology of the species has already been standardised at the Regional Research Centre of ICAR-Central Institute of Freshwater Aquaculture, Bangalore. B. carnaticus is characterised by an elongated and stocky body. Compared to other members of the genus, this species attains larger size; the maximum weight recorded being $12 \mathrm{~kg}$ and length $90 \mathrm{~cm}$ (Talwar and Jhingran, 1991). The higher growth rate of B. carnaticus in the first year of its life span along with other favourable characteristics makes this species an excellent candidate for freshwater aquaculture (Manojkumar and Kurup, 2010).

Proteins are the structural components and energy source in diets of fish and play a key role as they are very essential for body maintenance and growth. Generally, fish requires higher levels of protein in diets and this nutrient is the costliest dietary constituent. A significant reduction in feed cost can be achieved if diets with low protein could be fed to fish without compromising growth and health (Webster et al., 2000). However, inadequate protein in the diet results in reduction of growth. On the other hand, if too much protein is supplied in the diet, only part of it will be used to make new proteins and the remainder will be converted to energy (Wilson, 2002). Hence determination of optimum protein requirement for fish is the first step to the development of low-cost feeds. Earlier studies have given an estimate of the protein requirement of Indian cultivable carps using purified diets (Sen et al., 1978; Singh and Sinha, 1981; Rao, 1987; Singh et al., 1987; Singh and Bhanot, 1988; Swamy and Mohanty, 1988; Swamy et al., 1988; Mohanty et al., 1990). Jena et al. (2012) reported the protein requirement of the minor carp Labeo fimbriatus, to be $30.14 \%$ based on 
live weight gain. This study analysed the protein requirement of $B$. carnaticus as information pertaining to the protein requirement of a species is essential before it is introduced into the culture system.

For the present experiment, healthy fingerlings of B. carnaticus $(\mathrm{n}=180)$ having an average initial length of $6.40 \pm 0.267 \mathrm{~cm}$ and weight of $2.46 \pm 0.39 \mathrm{~g}$ were distributed into groups of 12 fish each and stocked randomly into 15 aerated plastic tubs (40 1). The fish were maintained under control feed for a week. Five feeds were formulated to contain crude protein (CP) levels ranging from 25 to $45 \%$ using pure ingredients such as casein, gelatin, dextrin, carboxy methyl cellulose, cellulose and agar (Table 1). The ingredients were thoroughly mixed in the desired proportions in a mechanical mixer with hot water and cod liver oil and vitamin mixtures added after cooling. The dough was pelletised using a hand proximate analysis. About $50 \%$ of water from each aquarium was replaced with freshwater every day after faecal matter collection. This feeding and faecal matter collection trial was conducted for a period of 60 days. Proximate composition of feed and faecal matter was analysed (AOAC, 1995). Nitrogen free extract was calculated based on the 'difference method' (Hastings, 1976). Acid insoluble ash (AIA) was used as the reference marker (Goddard and McLean, 2001; Li et al., 2008; Bob-Manuel, 2013) for dry matter, protein and fat digestibility determination (Maynard and Loosli, 1972).

Total dry matter digestibility $(\%)=100-\left[100 \times \frac{\% \text { AIA in feed }}{\% \text { AIA in faeces }}\right]$
Nutrient digestibility $(\%)=100-100\left[\frac{\% \text { AIA in feed }}{\% \text { AIA in faeces }}\right] \times\left[\frac{\% \text { Nutrient in faeces }}{\% \text { Nutrient in feed }}\right]$

Table 1. Ingredient proportion (\%) and proximate composition ( $\%$, mean $\pm \mathrm{SD})$ of experimental feeds.

\begin{tabular}{llllll}
\hline Crude protein (\%) & CP 25\% & CP 30\% & CP 35\% & CP 40\% & CP 45\% \\
\hline Ingredients & & & & & \\
\hline Casein & 25 & 28.59 & 33.36 & 38.13 & 42.89 \\
Gelatin & 5 & 5.91 & 6.64 & 7.59 & 8.54 \\
Dextrin & 30.1 & 30.61 & 23.36 & 15.9 & 8.46 \\
Cod liver oil & 8 & 8 & 8 & 8 & 8 \\
CM Cellulose & 12 & 12 & 12 & 12 & 12 \\
Agar & 2.5 & 2.5 & 2.5 & 2.5 & 2.5 \\
Vitamin mineral mix & 4.5 & 4.5 & 4.5 & 4.5 & 4.5 \\
Cellulose & 12.9 & 7.89 & 9.64 & 11.38 & 13.11 \\
\hline Proximate composition (\%) & & & & & $1.89 \pm 0.00$ \\
\hline Moisture & $1.78 \pm 0.31$ & $1.29 \pm 0.07$ & $1.51 \pm 0.04$ & $1.48 \pm 0.06$ & $44.51 \pm 0.74$ \\
Crude protein & $25.01 \pm 0.13$ & $30.30 \pm 0.30$ & $34.77 \pm 0.84$ & $39.00 \pm 0.37$ & $6.77 \pm 0.06$ \\
Fat & $7.66 \pm 0.40$ & $7.91 \pm 0.56$ & $6.55 \pm 0.18$ & $6.04 \pm 0.65$ & $8.71 \pm 0.02$ \\
Ash & $8.41 \pm 0.22$ & $8.49 \pm 0.19$ & $8.45 \pm 0.14$ & $8.65 \pm 0.08$ & $7.68 \pm 0.38$ \\
Crude fibre & $7.48 \pm 0.00$ & $6.23 \pm 0.26$ & $5.23 \pm 0.16$ & $6.71 \pm 0.11$ & $30.44 \pm 1.18$ \\
NFE & $49.66 \pm 0.28$ & $45.78 \pm 0.74$ & $43.49 \pm 1.26$ & $38.12 \pm 1.14$ & 17.93 \\
Gross energy (kJg-1) & 17.17 & 17.79 & 18.28 & 17.72 & \\
\hline
\end{tabular}

CP - Crude protein, NFE - Nitrogen free extract

pelletiser fitted with a $1 \mathrm{~mm}$ die and the extruded noodles were sun dried (to $<10 \%$ moisture). The sun dried feed were manually broken into small pieces and stored at room temperature $\left(26 \pm 2^{\circ} \mathrm{C}\right)$ in separate airtight containers till further use.

The experimental feeds prepared were given at $5 \%$ of the biomass initially and gradually adjusted based on the observation of daily feed consumption. The fish were allowed to feed for $6 \mathrm{~h}$. The unconsumed feeds were siphoned out at the end of the feeding period. On the following day's faecal matter was collected from each tank by filtering the water with a fine meshed nylon cloth $(15 \mu \mathrm{m})$, dried, pooled and stored for
The energy value of feed was obtained by multiplying protein, lipid and carbohydrate contents by factors 22.6, 38.9 and 17.2 respectively (Mayes, 1990) and expressed in $\mathrm{kJ} \mathrm{g}^{-1}$. During the experiment, water quality parameters, namely $\mathrm{pH}$, temperature, dissolved oxygen and total alkalinity were analysed at fortnightly intervals following standard methods (APHA, 1998). Water samples were collected between 09.00 and $10.00 \mathrm{hrs}$.

At the end of the experiment, the length and weight of the fishes were measured. The weight gained by the fingerlings, specific growth rate (SGR) and feed conversion ratio (FCR) for each feed were calculated. Data was analysed using one-way ANOVA. Whenever significant difference 
$(\mathrm{p}<0.05)$ was noticed, Duncan's multiple range test was done (Duncan, 1955) and results presented as mean \pm standard deviation.

The water quality parameters recorded during the experiment are given in Table 2. The growth parameters and protein efficiency ratio were higher $(p<0.05)$ in fish fed $35 \%$ protein diet compared to the other diets (Table 3). The FCR was lower $(\mathrm{p}<0.05)$ in 35,40 and $45 \%$ protein diets compared to the lower protein diets. No mortality of fish was observed in any of the experimental tubs during the study.

The carcass proximate composition revealed lowest moisture $(p<0.05)$ and highest protein content $(p>0.05)$ in fish fed $35 \%$ protein diet, there being no difference $(p>0.05)$ among the other treatments (Table 4). Further, the fat content $(\mathrm{p}<0.05)$ was also higher in fish fed $35 \%$ protein diet compared to other diets. The ash content was higher $(\mathrm{p}<0.05)$ with 25 and $30 \%$ protein diets.

The digestibility of dry matter (DMD) and nutrients showed higher $(\mathrm{p}<0.05)$ values with $35 \%$ dietary protein
Table 4. Carcass composition ( $\%$ on wet weight basis, mean $\pm \mathrm{SD})$ of B. carnaticus

\begin{tabular}{lllll}
\hline Feeds & Moisture & Crude protein & Fat & Ash \\
\hline CP 25\% & $75.97 \pm 0.57^{\mathrm{b}}$ & $16.76 \pm 0.40^{\mathrm{a}}$ & $3.14 \pm 0.18^{\mathrm{a}}$ & $3.62 \pm 0.08^{\mathrm{c}}$ \\
CP 30\% & $76.05 \pm 0.32^{\mathrm{b}}$ & $16.88 \pm 0.20^{\mathrm{ab}}$ & $3.24 \pm 0.12^{\mathrm{ab}}$ & $3.59 \pm 0.05^{\mathrm{cb}}$ \\
CP 35\% & $74.43 \pm 0.24^{\mathrm{a}}$ & $17.55 \pm 0.19^{\mathrm{b}}$ & $4.38 \pm 0.00^{\mathrm{e}}$ & $3.41 \pm 0.03^{\mathrm{a}}$ \\
CP 40\% & $75.94 \pm 0.36^{\mathrm{b}}$ & $17.00 \pm 0.14^{\mathrm{ab}}$ & $3.58 \pm 0.06^{\mathrm{bd}}$ & $3.32 \pm 0.04^{\mathrm{a}}$ \\
CP 45\% & $75.74 \pm 0.42^{\mathrm{b}}$ & $17.01 \pm 0.30^{\mathrm{ab}}$ & $3.39 \pm 0.20^{\mathrm{ab}}$ & $3.43 \pm 0.08^{\mathrm{ab}}$
\end{tabular}

(Fig. 1). While the total DMD showed a hyperbolic trend, the protein and nitrogen-free extract (NFE) digestibility showed an increasing and the fat digestibility a decreasing trend with the dietary protein level.

Studies with respect to protein requirements in fish have been conducted in many species before they were introduced in to the aquaculture system. Delong et al. (1958) were the first to use casein-gelatin based purified diets for studying the protein requirement of fish. Garling and Wilson (1976) reported a level of $25-36 \%$ crude protein in diets as optimum for warm water fishes. Fingerlings of Indian major carps

Table 2. Water quality parameters (mean $\pm \mathrm{SD})$ recorded in the experimental tubs

\begin{tabular}{llllll}
\hline Parameter & CP 25\% & CP 30\% & CP 35\% & CP 40\% & CP 45\% \\
\hline Temperature $\left({ }^{\circ} \mathrm{C}\right)$ & $25.1 \pm 0.319$ & $24.9 \pm 0.45$ & $25.6 \pm 0.23$ & $24.7 \pm 0.01$ & $25.3 \pm 0.14$ \\
pH (range) & $7.28-7.98$ & $7.29-8.00$ & $7.41-8.10$ & $7.35-8.00$ & $7.31-8.05$ \\
Dissolved oxygen $(\mathrm{ppm})$ & $5.86 \pm 1.11$ & $6.87 \pm 1.09$ & $7.16 \pm 1.12$ & $7.86 \pm 0.78$ & $5.67 \pm 0.49$ \\
Total alkalinity $(\mathrm{ppm})$ & $323.01 \pm 8.31$ & $327.87 \pm 7.61$ & $338.78 \pm 6.81$ & $330.16 \pm 5.26$ & $331.49 \pm 3.18$ \\
\hline
\end{tabular}

Table 3. Growth parameters (mean $\pm \mathrm{SD}$ ) of $B$. carnaticus recorded during the study

\begin{tabular}{llllll}
\hline Growth parameters & CP 25\% & CP 30\% & CP 35\% & CP 40\% & CP 45\% \\
\hline Initial weight (mg) & $2.38 \pm 0.05$ & $2.42 \pm 0.05$ & $2.34 \pm 0.01$ & $2.45 \pm 0.12$ & $2.47 \pm 0.11$ \\
Final weight (mg) & $3.22 \pm 0.18^{\mathrm{a}}$ & $3.23 \pm 0.07^{\mathrm{a}}$ & $3.79 \pm 0.21^{\mathrm{b}}$ & $3.73 \pm 0.13^{\mathrm{b}}$ & $3.57 \pm 0.12^{\mathrm{ab}}$ \\
Weight gain (\%) & $35.28 \pm 9.86^{\mathrm{a}}$ & $33.27 \pm 4.43^{\mathrm{a}}$ & $61.95 \pm 9.18^{\mathrm{b}}$ & $52.51 \pm 4.8^{\mathrm{ab}}$ & $45.02 \pm 7.10^{\mathrm{ab}}$ \\
SGR (\%) & $0.50 \pm 0.12^{\mathrm{a}}$ & $0.48 \pm 0.05^{\mathrm{a}}$ & $0.80 \pm 0.09^{\mathrm{b}}$ & $0.70 \pm 0.05^{\mathrm{ab}}$ & $0.62 \pm 0.08^{\mathrm{ab}}$ \\
Feed conversion ratio & $6.00 \pm 1.42^{\mathrm{b}}$ & $6.00 \pm 0.61^{\mathrm{b}}$ & $3.00 \pm 0.24^{\mathrm{a}}$ & $3.34 \pm 0.37^{\mathrm{a}}$ & $3.73 \pm 0.35^{\mathrm{a}}$ \\
Protein efficiency ratio & $0.69 \pm 0.18^{\mathrm{ab}}$ & $0.55 \pm 0.06^{\mathrm{a}}$ & $0.96 \pm 0.08^{\mathrm{bc}}$ & $0.77 \pm 0.09^{\mathrm{ab}}$ & $0.60 \pm 0.06^{\mathrm{a}}$ \\
\hline
\end{tabular}

Figures in the same row with different superscripts are significantly different $(\mathrm{p}<0.05)$.

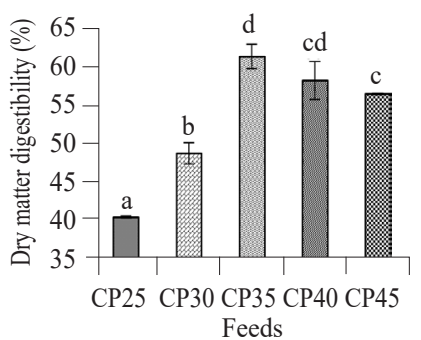

(a)

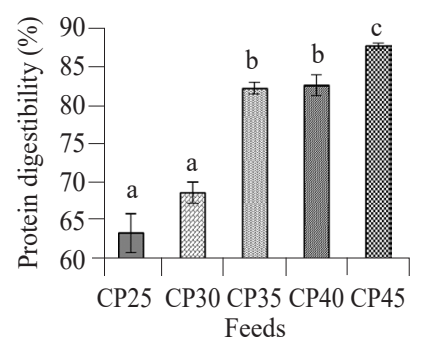

(b)

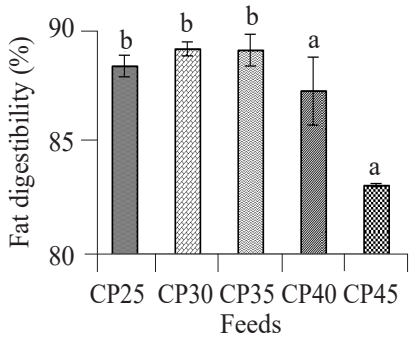

(c)

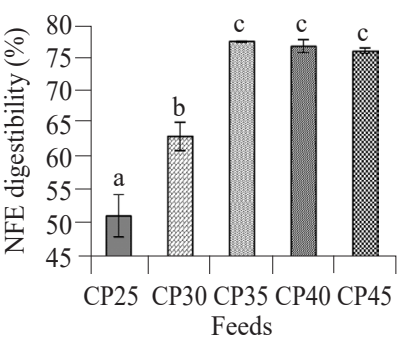

(b)

Fig. 1. Digestibility (mean \pm SD) of feed (DM) and nutrients (a: Dry matter; b: Protein; c: Fat; d: NFE) in B. carnaticus fed experimental feeds. Different alphabets on bars indicate statistical difference $(\mathrm{p}<0.05)$ 
require around $30 \%$ dietary protein for growth (Renukaradhya and Varghese, 1986; Murthy, 2003; Singh et al., 2006). Varghese et al. (1976) and Dabrowski (1977) reported the protein requirement of common carp and grass carp to be $31 \%$ and $41-43 \%$ respectively. L. fimbriatus, a medium carp has a dietary protein requirement of $30 \%$ based on live weight gain (Jena et al., 2012). In the present study, the growth parameters and protein efficiency ratio were higher $(\mathrm{p}<0.05)$ in fish fed $35 \%$ protein diet. Variation in dietary protein requirement of fish is due to difference in species, feeding habit, size (age) of the fish, water temperature, feed quality, feed composition, biological value of protein, source of non-protein energy and availability of natural feed (Halver et al., 1964; Garling and Wilson, 1976; Mazid et al., 1979; Dabrowski et al., 1989).

The growth parameters of $B$. carnaticus, feed conversion ratio and protein efficiency ratio showed a negative trend ( $>0.05$ ) above $35 \%$ protein level indicating more than the optimum level of dietary protein having adverse effects on growth of the species. Similar observation has been reported for catla (Dars et al., 2010), rohu (Nandeesha et al., 1991; Khan and Jafri, 1992; Chakraborthy et al., 1999), grass carp (Dabrowskyet al.,1977) and stunted fingerlings of rohu (Kumar et al., 2011) and catla (Ramaswamy et al., 2013). This decreased growth may be attributed to the metabolic stress mediated by excess nitrogen content.

PER is known to decrease with increasing dietary protein content, indicating decrease in protein utilisation with increasing dietary protein levels (Jauncey, 1982; De Silva et al., 1989; Khattab et al., 2000; Kumar et al., 2011). This is mainly because more dietary protein is used as energy when high protein diets are fed to fish (Kim et al.,1991). However, in the present study, decrease in PER was observed only above 35\% dietary protein level. Dabrowski (1979) opined that the relationship between dietary protein and PER differs from species to species.

The carcass composition of B. carnaticus was influenced significantly by dietary protein level. Fish fed $35 \%$ protein diet had lower content of moisture and higher protein and lipid than fish fed other diets. Singh et al. (2006) also reported highest amount of protein and lipid in the muscle of rohu at optimum dietary protein level. Carcass composition is known to be influenced by many factors like geographical location, age, sex, maturity and feeding conditions. An increase in muscle protein and a decrease in lipid content with increasing dietary protein was noted by Dabrowski (1977) in grass carp, Jauncey (1982) in Sarotherodon (=Oreochromis) mossambicus, Fah and Leng (1986) in guppy, Poecilia reticulata, Shiau and Huang (1989) in hybrid tilapia (Oreochromis niloticus x O. aureus), Kheir (1997) and Al-Hafedh (1999) in Nile tilapia (O. aureus). However, such a trend was not observed in the present study. The carcass ash content was higher in fish fed 25 and $30 \%$ protein diets compared to other treatments. Khattab et al. (2000) reported that ash content was unaffected by protein level in Nile tilapia.

The total DMD was higher with high protein diets. Ginindza (2012) recorded a positive correlation between apparent digestibility coefficients of protein and lipid with dietary protein level. High protein and lipid digestibility with increase in dietary protein content was also observed in Labeo rohita (Gul et al., 2007). In another study with rohu, Singh et al. (2005) reported that digestibility of protein was significantly higher in diets containing 30 and 35\% crude protein, however, with further increase or decrease in protein level, a significant decrease in apparent protein digestibility was observed. In a study with grass carp, the increase in dietary protein, did not affect protein, lipid and NFE digestibility (Koprucu, 2012). In the present study, the protein digestibility was the highest with high protein diets. However, lipid digestibility coefficients were the highest with lowest protein diet (25\%). The NFE digestibility was higher with high protein diets, this is particularly interesting due to the fact that these diets had low dietary NFE. It may be noted that the digestibility coefficients of DM and all the nutrients were the best with dietary crude protein level of $35 \%$, corresponding with the fish growth.

\section{References}

Al-Hafedh, Y. S. 1999. Effects of dietary protein on growth and body composition of Nile tilapia (Oreochromis niloticus). Aquac. Res., 30: 385-393.

APHA. 1998. Standard methods for the examination of water and wastewater, $20^{\text {th }}$ edn. American Public Health Association/ American Water Works Association/Water Environment Federation, Washington, DC, USA.

AOAC 1995. Official methods of analysis, $16^{\text {th }}$ edn. Association of Official Analytical Chemists, Washington DC, USA.

Bob-Manuel, F. G. 2013. Methods used in digestibility evaluation of fish diets: a review and challenges. Cont. J. Fish. Aquat. Sci., 7(2): 25-37.

Chakraborty, S. C., Chowdhury, S. A. and Chakraborty, S. 1999. Energy budget of Indian major carp, Labeo rohita fingerlings fed on diets with different protein levels. Asian Fish. Sci., 12: 297-308.

Dabrowski, K., Poczyczynski, P., Cock, G. and Berger, B. 1989. Effect of partially or totally replacement of fishmeal protein by soyabeen meal protein on growth, food utilisation and proteolytic enzyme activity in rainbow trout (Salmo gairdneri) new in vivo test for exocrine pancreatic secretion. Aquaculture, 77: 29-49.

Dabrowski, K. 1977. Protein requirements of grass carp fry (Ctenopharyngodon idella Val.). Aquaculture, 12: 63-73. 
Dabrowski, K. 1979. Feeding requirements of fish with particular attention to common carp, a review. Pol. Arch. Hydrobiol., 26: $135-158$

Dars, B. A., Narejo, T., Dayo, A., Lashari, P. K., Laghari, M. Y. and Waryani, B. 2010. Effect of different protein on growth and survival of Catla catla (Hamilton. reared in glass aquaria. Sindh Univ. Res. J., 42(1): 65-68.

Delong, D. C., Halver, J. E. and Mertz, E. T. 1958. Nutrition of salmonid fishes. Protein requirements of chinook salmon at two different water temperatures. J. Nutr., 65: 589-599.

De Silva, S. S., Gunasekera, R. M. and Atapattu, D. 1989. The dietary protein requirements of young tilapia and an evaluation of the least cost of diet protein levels. Aquaculture, 80: 271-284.

Duncan, D. B. 1955. Multiple range and multiple F tests. Biometrics, 11: $1-42$.

Fah, S. K. and Leng, C. Y. 1986. Some studies on the protein requirement of the guppy, Poecilia reticulate (Peters). J. Aquat. Sci., 44: 1-12.

Garling, D. L. and Wilson, R. P.1976. Effect of dietary protein to lipid ratios on growth and body composition of fingerling of channel cat fish. Prog. Fish Cult., 39: 43-47.

Ginindza, J. 2012. Effect protein levels on nutrient and energy digestibility in diet of Arctic charr (Salvilinus alpinus). United Nations University Fisheries Training Programme, Iceland [final project]. http://www.unuftp.is/static/fellows/ document/ joseph11prf.pdf.

Goddard, J. S. and McLean, E. 2001. Acid-insoluble ash as an inert reference material for digestibility studies in tilapia (Oreochromis niloticus). Aquaculture, 194: 93-98.

Gul, Y., Salim, M. and Rabbani, B. 2007. Evaluation of apparent digestibility coefficients of different dietary protein levels with and without fish meal for Labeo rohita. Pakistan Vet. J., 27(3): 121-125.

Halver, J. E., Bates, L. S. and Mertz, E. T. 1964. Protein requirement for sockeye salmon and rainbow trout feed. Fed. Proc., 23 (Abstract. 1778), 397pp.

Hastings, W. H. 1976. Fish nutrition and fish feed manufacture. Paper presented at FAO technical conference on Aquaculture, Kyoto, Japan, 13 pp.

Jauncey, A. 1982. The effect of varying dietary protein level on the growth, food conversion, protein utilisation and body composition of juvenile tilapias (Sarotherodon mossambicus). Aquaculture, 27: 43-54.

Jena, J. K., Mitra, G. and Biswal, S. 2012. Effect of protein levels on growth and nutrient utilisation of fringe-lipped carp, Labeo fimbriatus (Bloch) fingerlings. Aquac. Nutr., 18(6): 628-639.

Khan, M. A. and Jafri, A. K. 1992. Replacement of fish meal with offal meal in formulated diets for the carp fingerlings Labeo rohita (Ham.). J. Aquac., 2: 56-62.

Khattab, Y. A. E., Ahmad, M. H., Shalaby, A. M. E. and AbdelTawwab, M. 2000. Response of Nile tilapia (Oreochromis niloticus L.) from different locations to different dietary protein levels. Egyptian J. Aquat. Biol. Fish., 4(4): 295-311.

Kheir, M. T. 1997. Growth of Oreochromis niloticus (Linnaeus, 1758) raised on feeds with different protein levels. Egypt. J. Zool., 28: 65-76.

Kim, K., Kayes, T. B. and Amundson, C. H. 1991. Purified diet development and re-evaluation of the dietary protein requirement of fingerling rainbow trout (Oncorhyncus mykiss). Aquaculture, 96: 57-67.

Koprucu, K. 2012. Variability in the chemical composition of different cotton seed and sunflower meals influences their digestibility when fed to grass carp (Ctenopharyngodon idella). Aquac. Nutr., 18(6): 662-672.

Kumar, R. V., Ramesh, K. S., Patil, P., Naveen Kumar, B. T. and Manissery, J. K. 2011. Dietary protein requirement of stunted fingerlings of rohu, Labeo rohita (Hamilton) during grow-out stage. Ind. J. Fish., 58(4): 49-53.

Li, P., Webb, K. A. and Gatlin, D. M. 2008. Evaluation of acidinsoluble ash as an indicator for digestibility determination with red drum, Sciaenops ocellatus and hybrid striped bass, Morone chrysops x M. saxatilis. J. World Aquac. Soc., 39(1): 120-125.

Manojkumar, T. G. and Kurup, B. M. 2010. Age and growth of the Carnatic carp, Puntius carnaticus (Jerdon, 1849) from Chalakudy River, Kerala. Indian J. Fish., 57(1): 81-85.

Mayes, P. A. 1990. Nutrition, In: Murray, R. K., Graner, D. K., Mayes, P. A. and Rodwell, V.W. (Eds.), Harper's Biochemistry, $22^{\text {nd }}$ edn. Prentice Hall International Inc., USA, p. 571-579.

Maynard, L. A. and Loosli, J. K. 1972. Animal nutrition. $6^{\text {th }}$ edn. McGraw-Hill, New York.

Mazid, M. A., Tanaka, Y., Katayama, T., Rahaman, M. A., Simpson, K. L. and Chickester, C. O. 1979. Growth response of tilapia fingerlings fed isocaloric diets with variable protein levels. Aquaculture, 14: 235-246.

Mohanty, S. N., Swamy, D. N. and Tripathi, S. D. 1990. Growth, nutritional indices and carcass composition of the Indian major carp fry Catla catla, Labeo rohita and Cirrhinus mrigala fed four dietary protein levels. Aquac. Hung., 6: 211- 217.

Murthy, H. S. 2003. Nutrient requirements of Indian major carps. Global Aquaculture Advocate, April. p. 58-59.

NACA/FAO, 2000. Aquaculture development beyond 2000: The Bangkok Declaration and Strategy. Proceedings of the Conference on Aquaculture in the Third Millennium, 20-25 February 2000 Bangkok, Thailand. NACA, Bangkok and FAO, Rome, $471 \mathrm{pp}$.

Nandeesha, M. C., Srikanth, G. K., Keshavanath, P. and Das, S. K. 1991. Fish Nutrition Research in Asia, Special Publication No. 5, Asian Fisheries Society, Philippines, p. 75-81.

Ramaswamy, B., Naveen Kumar, B. T., Doddamani, P. L., Panda, K. and Ramesh, K. S. 2013. Dietary protein 
requirement of stunted fingerlings of the Indian major carp Catla catla (Hamilton) during grow-out phase. Indian J. Fish., 60(4): 87-91.

Rao, N. G. S. 1987. Studies on the growth of fry and fingerlings of selected carps fed on formulated fish feeds. Ph. D. Thesis, Bangalore University, Bangalore, India.

Renukaradhya, K. M. and Varghese, T. J. 1986. Protein requirement of the carps, Catla catla (Ham.) and Labeo rohita (Ham.). Proc. Indian Acad. Sci. (Anim. Sci.), 95: 103-107.

Sen, P. R., Rao, N. G. S., Ghosh, S. R. and Rout, M. 1978. Observation on protein and carbohydrate requirements of carps. Aquaculture, 13: 245-255.

Singh, P. K., Gaur, S. R., Barik, P., Sulochana, S., Shukla, S. and Singh, S. 2005. Effect of protein levels on growth and digestibility in the Indian major carp, Labeo rohita (Hamilton) using slaughter house waste as the protein source. Int. J. Agric. Biol., 7: 939-941.

Singh, P. K., Gaur, S. R. and Chari, M. S. 2006. Effect of varying protein levels on the growth of Indian major carp rohu, Labeo rohita (Hamilton). Int. J. Zool. Res., 2: 186-191.

Singh, B. N. and Bhanot, K. K. 1988. Protein requirements of the fry of Catla catla (Ham.). The First Indian Fisheries Forum Proceedings, Asian Fisheries Society, Indian Branch, Mangalore.

Singh, B. N. and Sinha, V. R. P. 1981. Observations on the nutrition of Indian major carp, Cirrhinus mrigala (Ham.). In: Abstract, All India Seminar on Fish Biology, Bihar University, Muzaffarpur, Bihar, India, 26-28 November 1981, 21 pp.

Singh, B. N., Sinha, V. R. P. and Kumar, K. 1987. Protein requirements of an Indian major carp, Cirrhinus mrigala (Ham.). Int. J. Acad. Ichthyol., 8(1): 71-75.
Swamy, D. N. and Mohanty, S. N. 1988. Response of rohu (Labeo rohita Ham) fingerlings to the diets of different protein contents. In: Proceedings of Third Asian Fish Nutrition Workshop, Asian Institute of Technology, Bangkok, 6-8 June, 1988. Asian Fisheries Society, Manila, Philippines.

Swamy, D. N., Mohantay, S. N. and Tripathi, S. D. 1988. Growth of mrigal fingerlings fed on fishmeal based formulated diets. In: Proceedings of the First Indian Fisheries Forum. 4 - 8 December 1987, Asian Fisheries Society (Indian Branch), Mangalore, India. p. 81-83.

Shiau, S. Y. and Huang, S. L. 1989. Optimal dietary protein level for hybrid tilapia (Oreochromis niloticus x O. aureus) reared in seawater. Aquaculture, 81: 119-127.

Talwar, P. K. and Jhingran, A. G. 1991. Inland fishes of India and adjacent countries. Oxford and IBH publishing Co. Pvt. Ltd. New Delhi, 1158 pp.

Varghese, T. J., Devaraj, K. V., Shantharam, B. and Shetty, H. P. C. 1976. Growth response of the common carp, Cyprinus carpio var. communis to protein rich pelleted feed. The symposium on development and utilisation of inland fishery resources, Colombo, Sri Lanka, 1997, p. 408-416.

Wilson, R. P. 2002. Protein and amino acids. In: Halver, J. E. and Hardy, R. W. (Eds.), Fish nutrition, $3^{\text {rd }}$ version, Elsevier Science, San Diego, USA, p. 144-179.

Webster, C. D., Thompson, K. R., Morgan, A. M., Grisb, Y. E. J. and Gannom, A. L. 2000. Use of hempseed meal, poultry by-product meal and canola meal in practical diets without fish meal for sunshine bass (Morone chrysops $\times$ M. saxatilis). Aquaculture, 188: 299-309. 